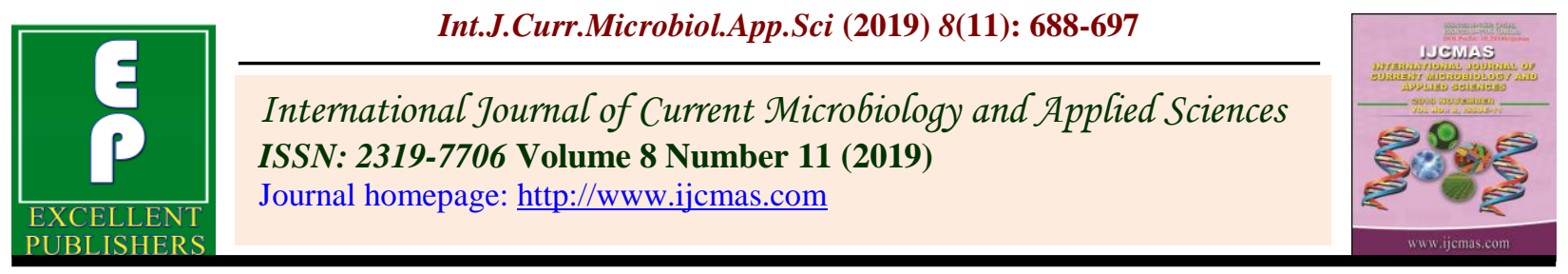

Original Research Article

https://doi.org/10.20546/ijcmas.2019.811.083

\title{
Epidemiological Studies of Tomato Leaf Curl Virus in Marathwada Region of Maharashtra, India
}

\author{
P.M. Khandare, D.N. Dhutraj and C.V. Ambadkar* \\ Department of Plant Pathology, College of Agriculture, Parbhani, Vasantrao Naik \\ Marathwada Krishi Vidyapeeth, Parbhani- 431402 (MS), India
}

*Corresponding author

\begin{tabular}{|l|}
\hline K e y w o r d s \\
Tomato, Leaf curl, \\
Epidemiology, \\
Whitefly
\end{tabular}

\section{A B S T R A C T}

The field experiment was conducted at Horticulture Research Scheme (Vegetable) VNMKV, Parbhani of during Rabi, 2017-18 and Summer 2018-19. The epidemiological studies viz., yield losses, vector population dynamics and disease incidence were recorded during the course of investigation. The tomato leaf curl virus disease of tomato has been found to cause heavy yield losses i.e. 96.80 and 98.43 in both Rabi and Summer season, respectively. However, the outbreak was not uniform throughout season. In Rabi season whitefly population and disease incidence was higher i.e. 2.06/ leaf and 25.94 per cent, respectively, whereas in Summer season whitefly population and disease incidence was 5.13/ leaf and 31.08 per cent, respectively. The whitefly population and disease incidence was relatively more in Summer than Rabi transplanting crop. A strong positive correlation was obtained between vector population dynamics and disease incidence in tomato plants.

\section{Introduction}

Tomato (Lycopersicon esculentum Mill.) is a good source of vitamins (A and C) and minerals. It is one of the most widely grown vegetable crop, highly popular due to its nutritive value, test and versatile use in various food items as salad as well as processed product like tomato sauce, pickle, ketchup, puree, dehydrated and of whole peeled tomatoes. The inferior quality of seed lack of advanced production technology, poor management practices and the impact of pest and diseases contribute to low yield (Varela 1995). In India the area, production and productivity was 789.2 thousand hectares, 19759.3 thousand metric tonnes and 25.0 metric tonnes respectively. In Maharashtra the area, production and productivity was 45.50 thousand hectare 1086.56 thousand metric tonnes and 23.88 metrics tonnes per hectares productivity respectively during 2017-18 
(Anonymous 2018). It is mostly grown in Pune, Nashik, Nagpur and Gadchiroli major producing district in Maharashtra. Tomato suffers on the account of many diseases caused by fungi, bacteria and viruses. Among these diseases leaf curl is one of most important in India including Maharashtra. The incidence of ToLCV in tomato growing areas of Karnataka ranged from 17-100 per cent in different seasons (Saikia and Muniyappa, 1989). Yield loss exceeds 90 per cent, when infection occurred within four weeks after transplanting in the field (Sastry and Singh, 1973; Saikia and Muniyappa, 1989). In many cases ToLCV epidemics lead to abandonment of the crop particularly in season/ periods favouring whitefly population buildup (Pico et al., 1996). However, attempts have been made to manage this disease of viral origin. The epidemiology of causal virus is essential for studying its management. Therefore present investigation has been undertaken keeping in view the economic importance of the crop and yield losses due to leaf curl virus disease in tomato.

\section{Materials and Methods}

To study the epidemiology of tomato leaf curl virus disease, a non replicated field experiment was conducted in Rabi season of 2017-18 and Summer season of 2018-19 at Horticulture Research Scheme (Vegetable) VNMKV, Parbhani with following details.

The transplanting was done with spacing $60 \times 45 \mathrm{~cm}$ on $17^{\text {th }}$ October in Rabi and $17^{\text {th }}$ January in Summer season. All recommended practices for tomato crop were followed.

The field was exposed to natural infection of the disease. Whitefly counts were recorded as per the method modified from Sipell et al., (1982). The whiteflies from bottom, middle, and top leaves of 10 randomly selected plants with an interval of 7 days from 7 to 90 days after transplanting were recorded. The diseased plants with an interval of 15 days were marked and recorded up to 90 days after transplanting.

For estimation of yield losses the observation in respect of number of fruits per plot, weight of fruits were recorded in both healthy and infected plant at various growth stages.

Vector population dynamics and correlation coefficient between vector and disease incidence, apparent infection rate and disease progress curve were worked out by using the observation recorded in respect of the vector and the disease.

\section{Estimation of yield losses}

Losses caused due to tomato leaf curl virus of tomato were assessed in Rabi 2017-18 and Summer 2018-19 by comparing the average yields of individual 10 healthy plants with 10 virus infected plants.

The plants infected with tomato leaf curl virus were tagged at 30, 45, 60, 75 and 90 days after transplanting. Observations such as number of fruits per plant, weight of fruits per plant and average yield per plant in grams were recorded from plant infected at different growth stages and randomly selected healthy plants. Assessment of losses due to disease was done on the basis of average yield per plant and expressed in terms of percentage by applying following formula.

Per cent loss in yield $=$

$$
\begin{aligned}
& \text { Average yield of_Average yield of } \\
& \text { Healthy plants diseased plants } \\
& \text { Average yield of healthy plants }
\end{aligned}
$$

Correlation and regression functions were worked out between stages of infection and 
other characters studied.

\section{Correlation between vector population dynamics and disease incidence}

To study the Whitefly population dynamics, the number of whiteflies were recorded from the three leaves i.e. top, middle and bottom of 10 randomly selected plants early in the morning i.e. before 7.30 A.M. Observation were recorded from 7 to 90 days after transplanting with an interval of 7 days. The average number of whiteflies per leaf was worked out.

The transformation of vector population was done by using Poison formula: $\sqrt{ } \mathrm{x}+0.5$, where $\mathrm{x}$ is the average number of vectors.

Simultaneously, incidence of leaf curl disease from 15 to 90 days after transplanting with an interval of 15 days was recorded and Per cent incidence of the disease was worked out. The correlation between whitefly population dynamics and incidence of the disease was worked out.

\section{Apparent infection rate (r)}

An apparent infection rate ( $r$ ) is the speedometer of epidemics of the plant diseases as described by Vander Plank (1963). Apparent infection rate was calculated to measure the epidemics of disease and to determine the vulnerable stage of the crop.

To work out apparent infection rate (r) of the disease, observations on disease incidence recorded were used. Based on infections recorded at an interval of 15 days an apparent infection rate $\mathrm{r}=\mathrm{dx} / \mathrm{x}(1-\mathrm{x})$ was calculated according to Vander Plank's equation (1963).

$$
r=\frac{2.3}{t_{2}-t_{1}} X_{2}\left(1-X_{1}\right)
$$

Where, $\mathrm{r}=$ Apparent infection rate $t_{2}-t_{1}=$ Days between first observation and subsequent observations

$\mathrm{X}_{1}$ and $\mathrm{X}_{2}=$ Amount of disease $(\% / 100)$ on $\mathrm{t}_{1}$ and $t_{2}$ dates, respectively.

\section{Progress of tomato leaf curl virus of tomato}

The disease progress curves were depicted as cumulative curves by plotting disease value $\log _{\mathrm{e}}(1 / 1-\mathrm{x})$ against time (Vander Plank, 1963).

\section{Results and Discussion}

The effect of tomato leaf curl virus on yield contributing factors and the yield of tomato was studied using cv. Pusa Ruby in both Rabi and Summer seasons. The data presented in Table 1 revealed that the losses were dependent on time of infection and season of cultivation.

The data revealed that, the infection occurred at seedling stage i.e. 30 days after transplanting caused severe losses in Rabi and Summer seasons. The losses reduced with delay in infection. They were minimum when the plants were infected at the time of maturity. The losses in cultivar were found to be higher in Summer than Rabi season.

In Rabi season, maximum losses of 96.80 per cent were recorded in cv. Pusa Ruby when, it was infected at 30 days after transplanting while, minimum losses were 6.24 per cent when, it was infected at 75 days after transplanting.

In Summer season, the losses were found to be higher than Rabi season. The maximum losses 98.43 per cent were recorded cv. Pusa Ruby when, it was infected at 30 days after transplanting in while, minimum losses were 5.44 per cent when, it was infected at 75 days after transplanting. 
The data in respect of fruit yield per plant as affected by tomato leaf curl virus is presented in Table 1. The data presented reveled that, the time of infection had conspicuous effect on yield of fruit in both the seasons. Apparently the losses were found more in cv. Pusa Ruby in both Rabi and Summer seasons. The fruit yield was found 48.30 and $20.40 \mathrm{gm}$. respectively when infection occurred at 30 days after transplanting. The yield per plant was 1509.73 and $1352.79 \mathrm{gm}$, respectively when infection occurred at 30 and 90 days after transplanting.

Growth and yield loss of tomato cv. Pusa Ruby due to ToLCV infection at different fortnightly interval was also investigated during the course of study. From the results it was clearly indicated that growth and yield increased with delay of ToLCV infection. The plants infected with in thirty days of transplanting recorded least growth and more yield loss. As infection delayed there was increased growth and yield over the check. The fruits formed in the early infected plants were very small and mummified.

The results of the present studies are in accordance with the results of different investigators who worked on this aspect. Sastry and Singh (1973) reported that ToLCV infected plant produced very few fruits when infected within 20 days after planting and resulting up to 92.30 per cent yield loss. While plants infected at 35 and 50 days after transplanting resulted in 82.9 and 74.0 per cent yield loss, respectively. Saikia and Muniyappa (1989) reported that tomato plants were susceptible to infection by ToLCV at all stages of their growth and found 50-70 per cent yield loss due to ToLCV infection in tomato cv. Pusa Ruby during February-May. Varma and Malathi (2003) reported that tomato leaf curl disease (ToLCD) is a serious and threatening disease of tomato, causing losses of up to 100 per cent in various parts of the world. Ajlan et al., (2007) reported that 96.90 per cent yield loss of tomato plant due to ToLCV in autum season. Reddy et al., (2011) reported that ToLCV was present in almost all fields of Belgaum, Dharward, Haveri districts of Karnataka with per cent disease incidence of 4 to $100 \%$ in Rabi and 60 to $100 \%$ during Summer season. Mishra et al., (2014) reported that tomato leaf curl virus disease is the most devastating both in terms of quantitative and qualitative yield losses. Often, the loss reaches to the extent of 100 per cent during Summer throughout India.

The data presented in Table 2 indicated that the yield contributing factors from 1 to 4 had significantly positive correlation with time of infection in both Rabi and Summer seasons while losses were found to be significantly negative correlated with time of infection in both Rabi and Summer seasons. The data on whitefly population dynamics and tomato leaf curl virus disease incidence as displayed in Tables 3 and 4. The data indicated that the occurrence of the vector in tomato crop was throughout the Rabi and Summer seasons. In Rabi season, the vector population was ranged from 0.0 to 2.06 whitefly per plant from $43^{\text {st }}$ standard week to $2^{\text {nd }}$ standard week. Highest whitefly population was observed in $51^{\text {th }}$ standard week when the average maximum temperature was $29.3^{\circ} \mathrm{C}$ and average minimum temperature $7.9^{\circ} \mathrm{C}$, with RH I and RH II i.e 75 and 27 per cent and wind velocity $3.8 \mathrm{Kmph}$, respectively. In Summer season, vector population was ranged from 0.00 to 5.13 whitefly per plant from 4 standard week to $15^{\text {th }}$ standard week. Highest whitefly population was observed in $13^{\text {th }}$ standard week when average maximum temperature $40.5^{\circ} \mathrm{C}$ and average minimum temperature $18.1^{\circ} \mathrm{C}$, with RH I and RH II i.e. 50 and 10 per cent and wind velocity $3.7 \mathrm{Kmph}$, respectively. 
Table.1 Experiment details

\begin{tabular}{|c|c|}
\hline Design & Non replicated \\
\hline Variety & Pusa Ruby \\
\hline Season & Rabi / Summer \\
\hline Spacing & $60 \times 45 \mathrm{~cm}$ \\
\hline Plot size & $10 \times 10 \mathrm{~m}^{2}$ \\
\hline
\end{tabular}

Table.2 Effect of tomato leaf curl virus on yield of tomato: losses in relation to the time of natural infection

\begin{tabular}{|c|c|c|c|c|c|c|c|c|}
\hline $\begin{array}{c}\text { Harvesting } \\
\text { (DAT) }\end{array}$ & \multicolumn{2}{|c|}{$\begin{array}{c}\text { Number fruit / } \\
\text { plant }\end{array}$} & \multicolumn{2}{|c|}{$\begin{array}{c}\text { Fruit weight } \\
\text { (g/Plant) }\end{array}$} & \multicolumn{2}{|c|}{ Av. Yield (g/Plant) } & \multicolumn{2}{|c|}{$\begin{array}{c}\text { Av. Yield losses } \\
\text { (\%) }\end{array}$} \\
\cline { 2 - 10 } & $\mathbf{R a b i}$ & Summer & $\mathbf{R a b i}$ & Summer & Rabi & Summer & Rabi & Summer \\
\hline $\mathbf{3 0}$ & 4.60 & 3.00 & 10.50 & 6.80 & 48.30 & 20.40 & 96.80 & 98.43 \\
\hline $\mathbf{4 5}$ & 8.40 & 7.70 & 35.51 & 31.80 & 298.28 & 244.86 & 80.24 & 81.89 \\
\hline $\mathbf{6 0}$ & 14.30 & 13.50 & 60.45 & 55.57 & 864.43 & 752.62 & 42.74 & 44.36 \\
\hline $\mathbf{7 5}$ & 18.30 & 17.60 & 77.35 & 72.68 & 1415.50 & 1279.16 & 6.24 & 5.44 \\
\hline $\begin{array}{c}\mathbf{9 0} \\
\text { (Apparentl } \\
\text { y Healthy) }\end{array}$ & 18.90 & 18.10 & 79.98 & 74.74 & 1509.73 & 1352.79 & -- & -- \\
\hline
\end{tabular}

DAT= Days after transplanting

Table.3 Correlation coefficient between time of infection of the virus causing tomato leaf curl disease with yield contributing factors and losses

\begin{tabular}{|c|c|c|c|}
\hline $\begin{array}{c}\text { Sr. } \\
\text { No. }\end{array}$ & Contributing factor & \multicolumn{2}{|c|}{ Correlation coefficient (r) } \\
\cline { 2 - 4 } & & Rabi & Summer \\
\hline $\mathbf{1}$ & Number of fruits per plant & $0.980^{* *}$ & $0.971^{* *}$ \\
\hline $\mathbf{2}$ & Weight fruits/ Plant (gms) & $0.968^{* *}$ & $0.951^{* *}$ \\
\hline $\mathbf{3}$ & Average yield per plant & $0.910^{*}$ & $0.901^{*}$ \\
\hline $\mathbf{4}$ & & & \\
\hline
\end{tabular}

NS= Non-Significant

$* *=$ Significant at $1 \%$

*Significant at $5 \%$ 
Table.4 Whitefly population dynamics in relation to incidence of tomato leaf curl virus in Rabi 2017-18 (Cv. Pusa Ruby)

\begin{tabular}{|c|c|c|c|c|c|c|c|c|c|}
\hline \multirow[t]{2}{*}{$\begin{array}{l}\text { Sr. } \\
\text { No. }\end{array}$} & \multirow[t]{2}{*}{ MW } & \multirow[t]{2}{*}{$\begin{array}{c}\text { Number of } \\
\text { whitefly / } \\
\text { leaf* }\end{array}$} & \multirow[t]{2}{*}{$\begin{array}{l}\text { Per cent } \\
\text { Incidence }\end{array}$} & \multirow[t]{2}{*}{$\mathbf{R F}$} & \multicolumn{2}{|c|}{$\begin{array}{c}\text { Temperature } \\
{ }^{\circ} \mathrm{C}\end{array}$} & \multicolumn{2}{|c|}{$\begin{array}{c}\text { Relative } \\
\text { Humidity } \\
(\%)\end{array}$} & \multirow[t]{2}{*}{$\begin{array}{c}\text { WS } \\
\text { (Kmph) }\end{array}$} \\
\hline & & & & & Max & Min & RH1 & RH2 & \\
\hline 1 & 43 & 0.00 & -- & 0.0 & 32.6 & 16.4 & 77 & 32 & 2.0 \\
\hline 2 & 44 & 0.00 & 2.70 & 0.0 & 30.9 & 14.5 & 78 & 31 & 2.6 \\
\hline 3 & 45 & 0.60 & -- & 0.0 & 30.8 & 12.2 & 79 & 31 & 3.4 \\
\hline 4 & 46 & 1.33 & 5.80 & 0.0 & 31.4 & 14.4 & 76 & 32 & 2.9 \\
\hline 5 & 47 & 1.46 & -- & 0.0 & 32.0 & 17.0 & 77 & 42 & 2.4 \\
\hline 6 & 48 & 1.73 & 14.86 & 0.0 & 29.9 & 10.2 & 77 & 31 & 2.9 \\
\hline 7 & 49 & 1.80 & -- & 0.0 & 30.4 & 14.4 & 75 & 42 & 4.7 \\
\hline 8 & 50 & 1.93 & 20.27 & 0.0 & 31.0 & 12.5 & 78 & 31 & 2.8 \\
\hline 9 & 51 & 2.06 & -- & 0.0 & 29.3 & 7.9 & 75 & 27 & 3.8 \\
\hline 10 & 52 & 1.80 & 25.94 & 0.0 & 25.6 & 6.1 & 67 & 19 & 2.7 \\
\hline 11 & 1 & 1.73 & -- & 0.0 & 29.6 & 9.2 & 76 & 32 & 2.6 \\
\hline 12 & 2 & 1.43 & 9.45 & 0.0 & 30.3 & 11.5 & 76 & 30 & 2.9 \\
\hline
\end{tabular}

* Figures in parentheses are $\sqrt{ } \mathrm{x}+0.5$ transformed values

Table.5 Whitefly population dynamics in relation to incidence of tomato leaf curl virus disease in Summer 2018-19 (Cv. Pusa Ruby)

\begin{tabular}{|c|c|c|c|c|c|c|c|c|c|}
\hline \multirow[t]{2}{*}{$\begin{array}{l}\text { Sr. } \\
\text { No. }\end{array}$} & \multirow[t]{2}{*}{ MW } & \multirow{2}{*}{$\begin{array}{c}\text { Number of } \\
\text { Whitefly / } \\
\text { leaf* }\end{array}$} & \multirow[t]{2}{*}{$\begin{array}{l}\text { Per cent } \\
\text { Incidence }\end{array}$} & \multirow[t]{2}{*}{$\mathbf{R F}$} & \multicolumn{2}{|c|}{ Temperature ${ }^{\circ} \mathrm{C}$} & \multicolumn{2}{|c|}{$\begin{array}{c}\text { Relative } \\
\text { Humidity }(\%)\end{array}$} & \multirow[t]{2}{*}{$\begin{array}{c}\text { WS } \\
\text { (Kmph) }\end{array}$} \\
\hline & & & & & Max & Min & RH1 & RH2 & \\
\hline 1 & 4 & 0.00 & -- & 0.0 & 29.9 & 8.7 & 78 & 25 & 3.1 \\
\hline 2 & 5 & 1.60 & 4.05 & 0.0 & 31.8 & 8.9 & 75 & 17 & 3.0 \\
\hline 3 & 6 & 2.33 & -- & 0.0 & 31.1 & 12.5 & 77 & 26 & 2.8 \\
\hline 4 & 7 & 2.33 & 8.10 & 3.6 & 30.9 & 14.2 & 81 & 36 & 4.6 \\
\hline 5 & 8 & 2.53 & -- & 0.0 & 34.8 & 14.8 & 69 & 21 & 3.2 \\
\hline 6 & 9 & 3.06 & 18.91 & 0.0 & 31.8 & 15.9 & 67 & 14 & 3.2 \\
\hline 7 & 10 & 3.46 & -- & 0.0 & 36.9 & 17.8 & 64.9 & 15.9 & 4.4 \\
\hline 8 & 11 & 3.53 & 24.05 & 6.1 & 33.5 & 19.3 & 71.6 & 32.7 & 3.3 \\
\hline 9 & 12 & 3.46 & -- & 0.0 & 37.7 & 17.0 & 74 & 14 & 4.4 \\
\hline 10 & 13 & 5.13 & 31.08 & 0.0 & 40.5 & 18.1 & 50 & 10 & 3.7 \\
\hline 11 & 14 & 2.53 & -- & 0.0 & 39.1 & 19.8 & 52 & 15 & 3.6 \\
\hline 12 & 15 & 1.73 & 12.60 & 0.0 & 39.1 & 22.5 & 52 & 18 & 4.2 \\
\hline
\end{tabular}

* Figures in parentheses are $\sqrt{ } \mathrm{x}+0.5$ transformed values 
Table.6 Correlation coefficient whitefly population and tomato leaf curl virus disease of tomato

\begin{tabular}{|c|c|c|}
\hline Season & Whitefly Population & $\begin{array}{c}\text { Per Cent Disease } \\
\text { Incidence }\end{array}$ \\
\hline Rabi & $0.778 * *$ & 1.000 \\
\hline Summer & 1.000 & $0.938 * *$ \\
\hline \multicolumn{2}{|c}{} \\
\hline
\end{tabular}

Table.7 Tomato leaf curl disease development and apparent infection rate (r) at different growth stages of tomato cv. Pusa Ruby

\begin{tabular}{|c|c|c|c|c|c|c|c|c|c|c|c|}
\hline \multicolumn{1}{|c|}{ Disease incidence (\%) days after sowing (cumulative) } & \multicolumn{5}{|c|}{$\begin{array}{c}\text { Apparent infection rate (r)* unit per day } \\
\text { at different growth stages. }\end{array}$} \\
\hline Season & $\mathbf{1 5}$ & $\mathbf{3 0}$ & $\mathbf{4 5}$ & $\mathbf{6 0}$ & $\mathbf{7 5}$ & $\mathbf{9 0}$ & $\mathbf{1 5 - 3 0}$ & $\mathbf{3 0 - 4 5}$ & $\mathbf{4 5 - 6 0}$ & $\mathbf{6 0 - 7 5}$ & $\mathbf{7 5 - 9 0}$ \\
\hline Rabi & 2.70 & 8.50 & 23.36 & 43.63 & 69.57 & 79.02 & 0.022 & 0.005 & 0.001 & 0.0005 & 0.0001 \\
\hline Summer & 4.05 & 12.15 & 31.06 & 55.11 & 86.19 & 98.19 & 0.012 & 0.004 & 0.001 & 0.0006 & 0.0001 \\
\hline
\end{tabular}

Fig.1 Rate of tomato leaf curl virus disease increases apparent infection rate (r) at different growth stages of tomato

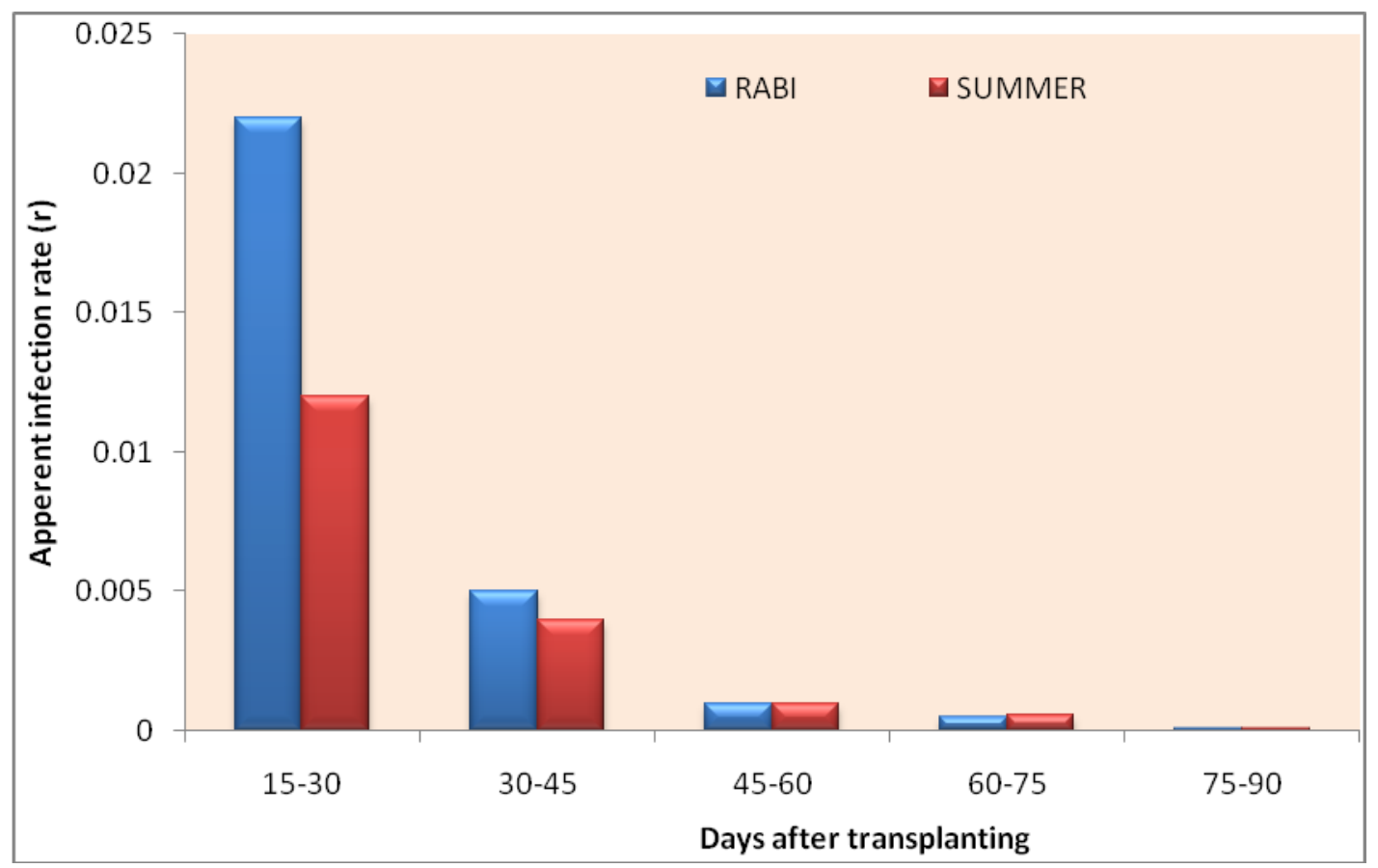


Fig.2 Progress of tomato leaf curl virus disease of tomato

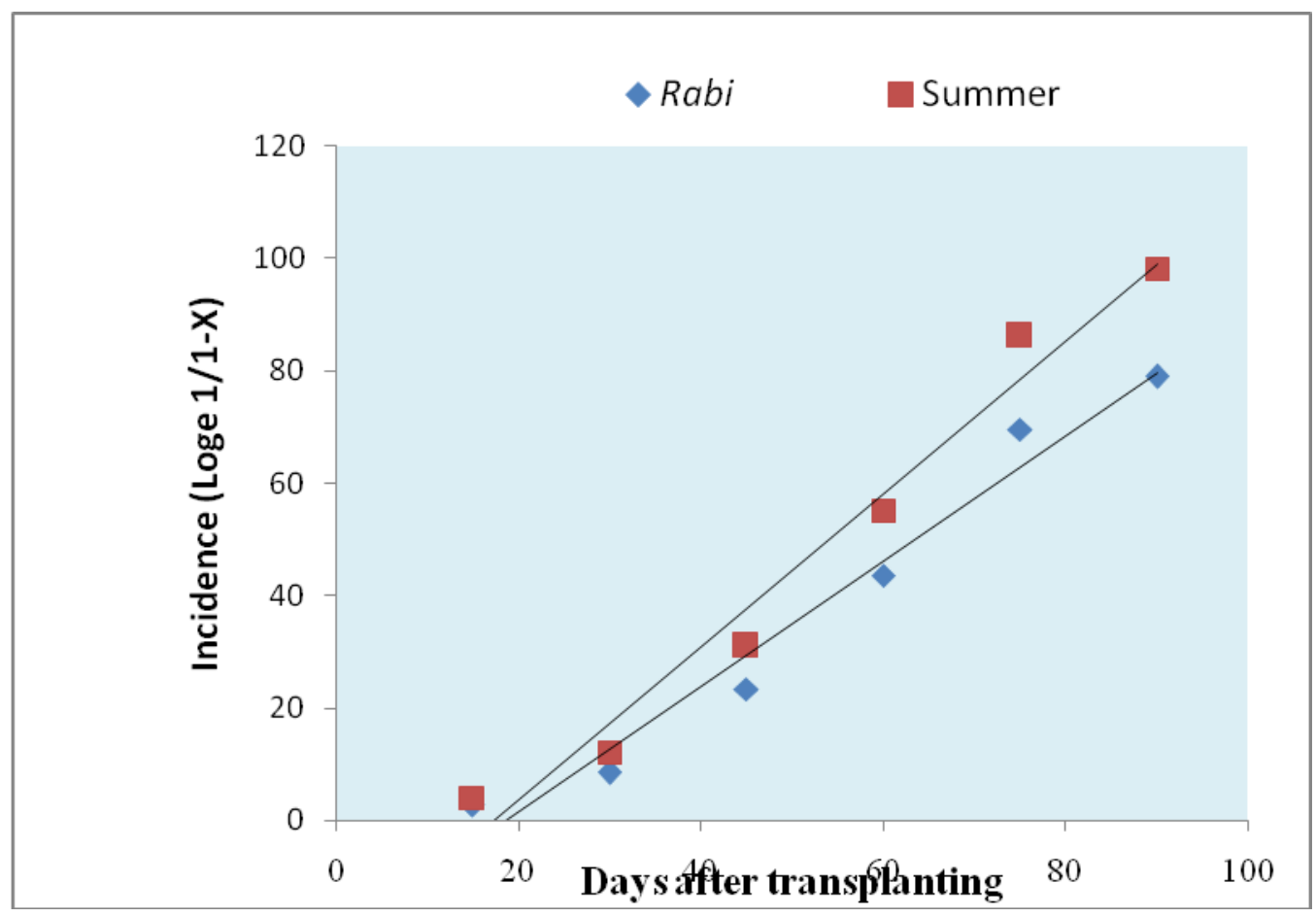

The first incidence of disease was observed after 46 standard week in $R a b i$ and $5^{\text {th }}$ standard week in Summer season. The disease incidence was seen throughout season of tomato. However, the outbreak was not uniform throughout season. The maximum incidence in Rabi was found in between $50^{\text {th }}$ standard week to $2^{\text {nd }}$ standard week, whereas, the maximum incidence in Summer was found in between $11^{\text {th }}$ standard week to $15^{\text {th }}$ standard week. The disease incidence was higher i.e. 25.94 and 31.08 per cent in Rabi and Summer season, respectively. The disease incidence was relatively more in Summer than the Rabi transplanting crop.

Correlation studies between whitefly population and per cent disease incidence were worked out and presented Table 5. Whitefly population and tomato leaf curl incidence were found significantly positive correlated in both Rabi ( $\mathrm{r}=0.778)$ and Summer ( $\mathrm{r}=0.938)$ seasons. The apparent infection rate was worked out in both Rabi and
Summer seasons. The data on apparent infection rate (r) is presented in Table 6 and graphically depicted in Fig, 1. The results revealed that the virus caused infection to sunflower throughout its growing period in both Rabi and Summer seasons which indicated that the crop was vulnerable to the leaf curl disease at all growth stages. However, in Rabi season the early growth stage i.e. 15-30 DAT, the growth period infection rate $r=0.022$ was noticed, whereas at 30 to 45 DAT the growth period the higher infection rate $(r=0.005)$ season was recorded which was found to be highly vulnerable. The infection rate was decreased with increased age of the crop. In Summer season the early growth stage i.e 15-30 DAT, the growth period infection rate $\mathrm{r}=0.012$ was recorded, whereas at 30 to $45 \mathrm{DAT}$, the growth period infection rate $(r=0.004)$ was recorded which were found to be highly vulnerable.

The tomato leaf curl disease progress curve is graphically depicted in Fig 2. The disease 
progress curve revealed that the progress of the disease in both the season was not uniform. The disease development in tomato was initiated from 30 days after transplanting in Rabi and Summer season and it prevailed throughout the season. The disease progress curve had clearly indicated that the disease developed very slowly at early crop growth stages in both Rabi and Summer season. Later the rate of development was increased with increase in age of the crop. In both seasons the progress of disease was found slower in initial stages and become faster in later stages of the crop. The results of the present study are correlate with the report of Honrao (1986) who reported that progress of tomato spotted wilt disease in early transplanted tomato i.e. July crop, was slower than the late transplanted tomato i.e. August crop. He found that during Kharif season in all cultivars disease development was slow at initial stage and faster in later stages. In Rabi season, disease development was slower in Pusa Ruby followed by ATV-2 Naveen and La-Bonita throughout growth period. Nirmal et al., (1993) reported the tomato spotted wilt disease in tomato occurred 30 days after transplanting during 1991, whereas, 45 days after transplanting during 1992 and 1993. Thus the faster development of the disease was at earlier growth stages. In subsequent growth stages the rate of its development slowed with increase in age of the plant. Similar results with regard to disease incidence, vector population and infection rate are reported by Aboul-Ata et al., (2000); Rahman et al., (2006) ; Bonato et al., (2007) and Rashid et al., (2008).

\section{References}

Anonymous, 2018. Indian Horticulture Database, National Horticulture Board Progress Report, 2017, p.247.

Aboul, Ata., Awad, A.E., Aziz, M.A.E., Abdel, S., Peters, D., Megahed, H. and
Sabik, A. 2000. Epidemiology of tomato yellow leaf curl begomovirus in the Fayium area, Egypt. Diseases of cucurbitaceous and solanaceous vegetable crops in the Mediterranean region, Kerkyra, Greece, 11-14 October 1999. Bulletin OEPP. 30 (2) : 297-300.

Ajlan, A. M., Ghanem, G. A. M. and Abdulsalam, K. S. 2007. Tomato yellow leaf curl virus (TYLCV) in Saudi Arabia: Identification, partial characterization and virus vector relationship. Arab Journal of Biotechnology, 10 (1): 179-192.

Bonato, O., A. Lurette, C. Vidal and J. Fargues. 2007. Modelling temperature dependent bionomics of Bemisia tabaci (Q-biotype). Physiological Entomology, 32: 50-55.

Honrao, S. M. 1986. Investigation on tomato spotted wilt virus infecting tomato. M.Sc. (Agri.) Thesis submitted to M.A.U. Parbhani.

Nirmal, D. D., Sirsat, A. B. and Pawar, B. R. 1993. Epidemiology and management of spotted wilt of tomato caused by tomato spotted wilt virus. Final report (Oct.1990 to Oct.1993). An Adhoc Scheme sponsored by ICAR.

Mishra, S., Kavi, S. J., Palliath U. K. and Sagar, P. 2014. Biocontrol of Tomato leaf curl virus (ToLCV) in tomato with chitosan supplemented formulations of Pseudomonas sp. under field conditions. Australian J. Crop Sci., 8(3):347-355.

Pico, B., Diez, M. J. and Nuez, F. 1996. Viral diseases causing the greatest economic losses to the tomato crop. II. The tomato yellow leaf curl virus - a review. Scientia Horticultural. 67 (34): 151-196.

Rahman, A., A. M. Akanda and A. K. M. A. Alam. 2006. Relationship of Whitefly Population Build up with the Spread of 
TYLCV on Eight Tomato Varieties. Journal of Agriculture \& Rural Development, 4 (1\&2):67-74.

Rashid, M., I. Hossain, A. Hannan, S. Uddin and M. Hossain. 2008. Effect of different dates of planting time on prevalence of Tomato yellow leaf curl virus and whitefly of tomato. J. Soil Nature, 2: 1-6.

Reddy, A. B., Patil, M. S. and Rajasekaram, T. 2010. Effect of Tomato leaf curl virus infection on plant growth and yield in tomato. Karnataka J. Agric. Sci., 23 (5): 806.

Reddy, B. A., Patti, M. S., Reddy, K. M. and Venkatara Vanappa, V. 2011. Detection and diagnosis of tomato leaf curl virus infecting tomato in Northern Karnataka. African Journal of Agricultural Research, 6 (5): 10511057.

Saikia, A. K. and Muniyappa, V. 1989. Epidemiology and control of tomato leaf curl virus in Southern India. Tropical Agriculture, 66:350-354.

Sastry, K. S. M. and Singh, S. J., 1973.
Assessment of loss in tomato by tomato leaf curl virus. Indian Journal of Mycology and Plant Pathology, 27:274-297.

Sipell, D. W., O. S Bindra and H. Khalifa., 1982. Prelimary study of relationship of leaf lobing and hair density in cotton with whitefly (Bemisia tabaci) population and proposal for further investigation Gerira Agric. Res. Stn., Agric. Res. Crop Wadmedani Sundan, working proper, 9:6.

Vander plank, J. E., 1963. Plant disease, epidemics and control. Academic press, New York: pp.349.

Varma, A. and Malathi, V. G. 2003. Emerging Geminivirus problem: A serious threat to crop production. Ann. Appl. Biol. 142 (2): 145-164.

Varela A. M. 1995. Major pest of tomatoes in eastern and southern Africa compilation of past research work and identification of IPM opportunities. GTZ- IPM. Horticulture project consultancy report, Nairobi, Kenya

\section{How to cite this article:}

Khandare, P. M., D.N. Dhutraj and Ambadkar, C.V. 2019. Epidemiological Studies of Tomato Leaf Curl Virus in Marathwada Region of Maharashtra, India. Int.J.Curr.Microbiol.App.Sci. 8(11): 688-697. doi: https://doi.org/10.20546/ijcmas.2019.811.083 